\title{
Korea's 2015 cigarette tax increases
}

\author{
Rajeev Cherukupalli
}

\section{Correspondence to}

Dr Rajeev Cherukupalli, Johns Hopkins University Bloomberg School of Public Health,

624 N. Broadway, Baltimore, MD 21205, USA:

rcheruku@jhu.edu

Received 18 November 2014 Accepted 5 January 2015

Published Online First

11 February 2015

\section{SLinked}

http://dx.doi.org/10.1136/ tobaccocontrol-2014-051680

\section{CrossMark}

To cite: Cherukupalli R. Tob Control 2016;25:123-124.

\section{ABSTRACT}

South Korea increased tobacco taxes in 2015 after a 10-year gap. This commentary suggests two lessons for public finance practitioners. Substantive tax increases are crucial to reducing tobacco use; particularly where prices are demonstrably lower and prevalence higher in comparison to other countries ranked similarly on economic development indicators. Second, as a rule of thumb, governments cannot afford to neglect the annual increases that ensure that tobacco taxes do not lose their efficacy over time.

Inflation erodes the value of fixed-price taxes over time, reducing both their effectiveness and the value of governments' excise revenues. It is therefore surprising that more countries have not adopted an automatic annual inflation adjustment in their tobacco taxes.

The government of the Republic of Korea recently elected to increase cigarette taxes for the first time in a decade. ${ }^{1}$ By 2014, the per-pack tax of 1550 won-introduced in 2005-was equivalent to less than 1250 won, a $20 \%$ decline in real terms. If the tax had been pegged to the consumer price index, it would instead have risen to nearly 2000 won.

South Korea's decision to raise taxes to nearly 3318 won per pack ${ }^{1}$ is commendable, and of particular importance for a country with one of the highest levels of tobacco use globally ( $44 \%$ of men and $27.7 \%$ of all adults are smokers) and, as figure 1 depicts, the cheapest cigarettes within the OECD. ${ }^{2}$ The government will also raise taxes annually in line with consumer price inflation. Taken together, these decisions raise pack prices, rectify a decade of nonincreasing taxes, and prevent future erosion in the real value of the tax. All three actions make eminent public health and fiscal sense, and are long overdue.

As a timely article in this issue makes clear, ${ }^{3}$ fears of the regressiveness of tobacco tax increases can be misplaced. Indirect taxes are, in general, regressive: poorer smokers pay a larger fraction of their incomes as cigarette taxes. Choi analyses data from 1998 to 2011 to show that smoking prevalence in Korea declines with rising income, but that the poorest smokers are the most price-responsive. This finding suggests that tax-induced quits will be highest among those with the highest burden of tobacco use.

Choi's article should go some way to assuaging concerns that the poorest will bear the largest economic burden of cigarette price increases in Korea. Part of the proposed higher tax is an 841 won (US $\$ 0.77)$ levy per pack to be directed towards the National Health Promotion Fund, with the intention that this will help fund cessation support programmes. $^{3}$ Addressing the most economically vulnerable through such spending may help reduce health inequalities.

Korea's cigarette tax increase underscores a larger theme for public finance practitioners in other

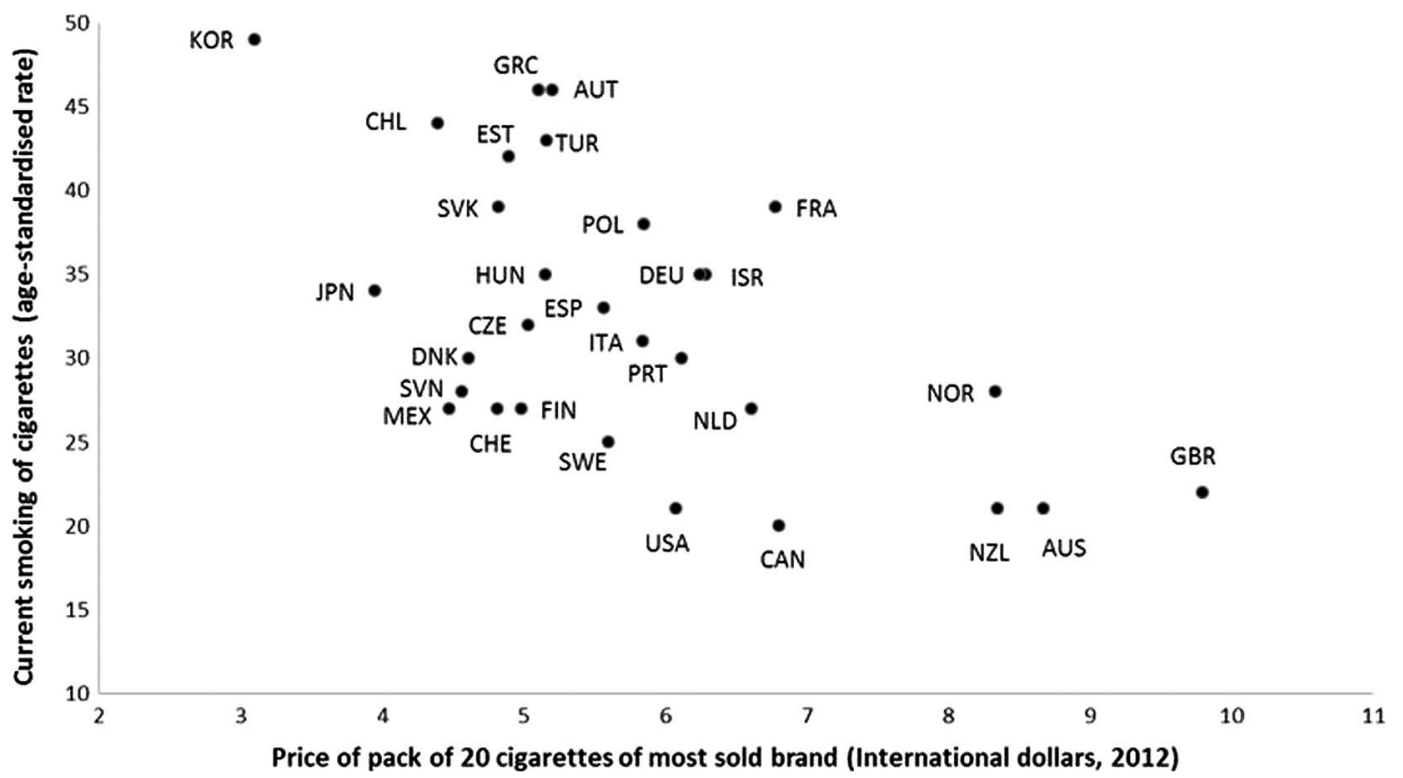

Figure 1 Adult male prevalence and purchasing power-adjusted prices of most sold brands in the OECD countries, 2012. Age-standardised prevalence used for comparability across countries. Data sourced from the WHO Report on the Global Tobacco Epidemic, 2013: enforcing bans on tobacco advertising, promotion and sponsorship. Belgium, Iceland, Ireland and Luxembourg omitted because estimates of age-standardised male current smoking were not available. Graph labels are 3-digit country ISO codes (KOR=South Korea). 


\section{Editorial}

countries-it is possible to 'normalise' tobacco tax increases and inflation adjustments as sound public policy. Between 1993 and 2000, the UK implemented a tobacco duty 'escalator', raising taxes annually above inflation. Australia has consistently raised its cigarette taxes and moved to close tax loopholes. ${ }^{4}$ In the USA, the 2009 federal cigarette tax increase, from $\$ 0.39$ to $\$ 1.01$ per pack, came at a time when the tax had fallen in real terms to less than $70 \%$ of its 1960 value. $^{5}$ While a one-time decision to raise tobacco excises is often contested, automatic mechanisms to prevent existing taxes from losing their bite should not be.

\section{Competing interests None.}

Provenance and peer review Commissioned; internally peer reviewed.

\section{REFERENCES}

1 Kim C, Kim R. Cigarette prices to surge in Korea as park raises taxes. Bloomberg News 11 September2014. http://www.bloomberg.com/news/2014-09-11/ cigarette-prices-to-surge-in-korea-as-park-raises-taxes.html

2 Song S-H, Lee $\mathrm{H}$-J. Tax hike will push price of cigarette packs up 80\%. Korea JoongAng Daily 12 September 2014. http://koreajoongangdaily.joins.com/news/ article/Article.aspx?aid=2994741

3 Choi S-E. Are lower income smokers more price sensitive?: the evidence from Korean cigarette tax increases. Tob Control 2016;25:141-6.

4 Australian Government Department of Health. The history of tobacco excise arrangements in Australia since 1901. Last reviewed 8 May 2014. http://www. health.gov.au/internet/main/publishing.nsf/Content/tobacco-tax (accessed 18 Nov 2014).

5 Campaign for Tobacco Free Kids. The Federal Tobacco Tax is much lower than historical levels [internet factsheet]. 2007. http://www.tobaccofreekids.org/research/ factsheets/pdf/0092.pdf (accessed 18 Nov 2014). 